\section{RALEIGH'S ATTEMPTED COLONIZATION OF VIRGINIA}

\section{The Roanoke Voyages 1584-1590}

Documents to illustrate the English voyages to North America under the Patent granted to Walter Raleigh in 1584. Edited by Prof. David Beers Quinn. Vol. 1 : pp. $x x \times v+496$. Vol. 2 : pp. vi $+497-1004$. (Works issued by the Hakluyt Society. Second Series, No. 104.) (London: Cambridge University Press, 1955.) 120s. net.

$\mathrm{T}$ these two most valuable and fascinating volumes 1 Prof. D. B. Quinn has continued for the colonization of Virginia under Raleigh what he had earlier completed for Sir Humphrey Gilbert's ventures in New England and Newfoundland. Spain, through Columbus, discovered the Caribbean lands, and within fifty years or so her empire stretched from California to Tierra del Fuego. Portugal, using Vespucci, coasted Brazil and Argentina and began its colonization in earnest by 1550 . But England, which through John Cabot had explored from Greenland to New Fingland, made no attempt to establish a colony in the New World. The Tudor monarchs sensed, almost immediately, that such voyages westward would not lead easily to Cathay and the Spice Islands, and so, apart from the fisheries of Newfoundland, English interest in the Americas lapsed until 1578. Gilbert's warrant to establish colonies in North America lasted from 1578 until 1584, and thereafter Sir Walter Raleigh obtained the Queen's patent to do so, provided he did not interfere with the Newfoundland fisheries.

Hakluyt published many of the main sources for the voyages and colonization of Virginia undertaken between 1584 and 1590. The documents in these two volumes include those of Hakluyt supplemented by many minor documents and new material and interpretations derived from modern scholarship. Vol. 1 includes seventy-three docurnents dealing with the 1585 and 1586 voyages, while Vol. 2 has thirtyfour English documents on the 1587-90 voyages, together with fifty-two Spanish documents, two of them published originally by Miss Wright, which deal with these Fnglish voyages to Roanoke Island in Virginia.

The introduction, of seventy-six pages, assesses the material, and at the beginning of each chapter a narrative is given of the events and material in the documents. Footnotes and annotations are most liberal and reveal the thorough and rich scholarship of the editing. Prof. Quinn considers that during 1584-86 the English ventures were not over-publicized, probably because of the danger of Spanish interference. From 1587 onwards, relations with Spain were open war if not official war, and after the defeat of the Armada there was no further fear of Spain. The documents published by Hakluyt were in the nature of propaganda for the colony, and Quinn believes that they suppressed some features of the expeditions to present the project in as attractive a light as possible. He also considers there is evidence to show that Raleigh and Grenville intended to establish a colony at about $36^{\circ} \mathrm{N}$., which would be sufficiently north of Florida to avoid. Spanish attack yet close enough to the West Indies to provide a base for privateering. It is this potential role of the Virginia colony on Roanoke which led the Spaniards to keep on searching to destroy it from 1590 until 1600 , unaware that it had been abandoned in 1590 .
The 1584 voyage located Roanoke Island, while Grenville's voyage of 1585 established a fort and colony on it. Lane was left with a garrison, expecting Raleigh to send a relief ship and stores by Easter 1586. It did not come until late June, and by then Lane and the colonists had been taken off by Drake, at their request. Grenville arrived with three hundred men two weeks later to strengthen the colony, but finding it deserted he left a holding party of only eighteen men, who were attacked by Indians and overcome. By such a narrow margin did the fair enterprise of Raleigh's colonization of Virginia fail to succeed : as Quinn notes, "the whole sequence of colonization was destroyed, inadvertently, by Drake". The drawings by White and the maps by White and Hariot, no less than their accurate descriptions of the Indians and the flora and fauna, are historical documents of unique value. There are appendixes on the map of Virginia as it was explored in these expeditions, on Indian words and on the archæology of the settlements. By 1950 the fort made in 1585 on Roanoke was completely reconstructed by Harrington. Sources and indexes of subjects, names and places complete a most comprehensive and brilliant study of this early venture in the origins of the British Empire. Prof. Quinn and the Hakluyt Society are to be warmly congratulated on this absorbing and scholarly addition to their famous series.

Ar'THUR DAvies

\section{LUCUBRATORY BIOCHEMISTRY}

\section{Biochemistry}

An Introductory Textbook. By Prof. Felix Haurowitz. Pp. xvi +485. (New York: John Wiley and Sons, Inc.; London: Chapman and Hall, Ltd., 1955.) 54s. net.

A CCORDING to the author, this text-book "is designed to form the basis of a one-semester course in biological chemistry intended for seniors and graduate students majoring in bacteriology, botany, chemistry, physiology, or zoology". After an introductory chapter, in which the development and scope of biochemistry, the fundamentals and special fields of the subject, and the literature, are all discussed, chapters are devoted to water and its functions, the mechanism of biochemical reactions, the chemistry and metabolism of carbohydrates, proteins and lipids, nucleic acids, porphyrins, mineral metabolism, enzymes, energy balances and nutrition, and human biochemistry. The balance of the book is different from the sort of volume that is produced for medical students, and includes both structural and dynamic aspects of the subject. It incorporates material on animal, plant and bacterial biochemistry.

Since the book is meant for seniors and graduate students it would seem all the more important that it should be accurate in detail, with an adequate discussion of the evidence on which the accepted ideas about metabolic processes are based. To produce a book for graduate students in a subject which is developing as rapidly as biochemistry advances to-day is a problem to be faced by all careful writers with some alarm and with intense care for detail and form. Dr. Haurowitz's book reveals little evidence of his awareness of these needs. Although the book is meant for seniors, references to original publications are not given in most instances. Such references as are included are largely to books and to review 